upper division of the latter ; an opinion probably in harmony with that of Sir H. De la Beche already quoted.

In an earlier paper on this subject-based exclusively on the statistics of the invertebrate fossils of Devon and Cornwall, considered both specifically and generically-I expressed the opinion, that the lowest beds of Devonshire do not constitute the basement of the Devonian system, and that the Barnstaple beds were rather Carboniferous than Devonian, or were, perhaps, "passage-beds" between them.* It is not without interest to find this opinion supported by the more reliable, because vertebrate, evidence now produced. It will be remembered, too, that the indications of the Holoptychian scale, already mentioned as having been described by Professor Phillips, and which was also found in the Meadfoot slates, are to the same effect.

Like the Old Red Sandstone fish found in Russia by Sir R. Murchison, the Phyllolepis scale was surrounded with marine shells, $\uparrow$ and also by corals of the family Cyathophyllide; the ancient fish to which it belonged was therefore not incapable of living in the sea.+

\title{
NOTICE OF FOSSILIZED MAMMALIAN REMAINS FROM THE BED OF THE GERMAN OCEAN.
}

By C. B. Rose, F.G.S., ETo.

It has for a very long period been known that, during the degradation of the cliffs of the counties of Norfolk, Suffolk, and Essex, teeth and bones of various mammals have been exhumed, and more largely those of pachyderms.

In Queen Elizabeth's time, huge bones were found at Walton, near Harwich. They were then considered to be those of giants. In the 'Philosophical Transactions' for 1745 , a Mr. Baker records the finding of a fossil elephant at Mundesley Cliff; and, in 1746, Mr. Wm. Arderon, of Norwich, makes mention of similar remains discovered at Hasborough and Walket, on the Norfolk coast. My present object is, to lay before you a few of the specimens which have been brought up from the bed of the German Ocean, entangled in the trawling nets of the Yarmouth fishermen. Had they been more portable, I would have exhibited tusks and other large remains of these huge beasts, of which there are some fine specimens in the collection of Messrs. Owles, Steward, Nash, and my own. The late Miss Gurney, of Northreps, was the possessor of a large collection of fossil mammals from the cliffs of Cromer and its vicinity, and which may now be seen in the Museum at Norwich. The Rev. John Gunn, of Irstead, has made an extensive and rich collection of similar remains, from Mundesley and Hasborough.

In the course of years vast numbers of teeth and bones have been collected. The late $\mathrm{Mr}$. Woodward, of Norwich, says, in his 'Geology of Norfolk,' "Mammalian remains have been dredged up on the Knole Sand, off Hasborough. This spot presented us, in 1826, with the finest tusk of the mammoth ; it measured $9 \frac{1}{2}$ feet along its curvature, and weighed $97 \mathrm{lbs} . "$ But off Dungeness a tusk was dredged up which measured 11 feet in length, and yielded some pieces of ivory fit for manufacture. The oysterbed off Hasborough was discovered in 1820 , and, from the number of grinders of the elephant found there, Mr. Woodward felt himself war-

* 'Geologist,' vol. v. pp. 28 and 31. + 'Siluria,' 3rd edit., pp. 383 and 433.

+ This scale has been transmitted to me and will shortly be figured. - BD. GEoc. 
ranted in concluding that upwards of 500 animals were deposited in that limited space.

The coloured map of the German Ocean exhibited at the meeting, showed the localities whence the organic remains are chiefly taken; certain spots marked thereon are the fishing-grounds, and, therefore, the depositories of the fossils with which we are made familiar; but we cannot doubt that these exuviæ are more generally distributed orer the sea-bottom. The following specimens were exhibited:-Teeth of three species of elephant, Elephas primigenius, $\boldsymbol{E}$. antiquus, and $E$. meridionalis ; cervical and dorsal vertebræ of the same genus; two teeth of a hippopotamus (a dorsal vertebra has since been brought up) ; a dorsal vertebra of a whale ; a unique specimen of a lower jaw of the Trichechus rosmarus; heads of the Megaceros Hibernicus, male and female; an anterior dorsal vertebra of ditto (an antler, 4 feet 6 inches long, has since been brought me) ; atlas of ditto; a fragment of an antler of Cervus tarandus; the humerus of a gigantic ox; a portion of the head of the Equus fossilis; and a fine specimen of Castor Europaus, the head. The colour of these specimens might lead us to believe that they belonged to the Mammaliferous Crag period; but colour is not a decisive criterion. It is probable that they may have lain in close proximity to a bed of crag ; they are unquestionably from a Pleistocene deposit.

And, now, as to how these organic remains came to be at the bottom of the ocean. At a not very remote geological period our island was united with the continent; a catastrophe took place which separated them and led to the formation of the German Ocean. This gap has been continually enlarging, from the crumbling down of the cliffs on either side; the fossils have thus been exhumed, carried out to sea during storms by retiring waves, and there deposited. No doubt, also, that many remains which lie buried in the land that originally united us to the continent sank bodily with it, and consequently they are met with when the sea-bottom is raked over by the trawling-nets of the fishermen.

P.S.-I give the measurement of three tusks. One, belonging to $\mathrm{Mr}$. Owles, measures-length of external curve, 7 feet 5 inches; girth at proximal end, 18 inches; radius of inner curve, 3 feet.

$I$ possess two perfect tusks-one, length, 6 feet 3 inches ; girth, 17 inches; radius of curve, 3 feet 3 inches: the other, length, 6 feet ; girth, $12 \frac{1}{2}$ inches; radius of curve, 4 feet 2 inches. These proportions indicate that my specimens are from two distinct species of the elephant.

A femur of the mammoth in my possession measures 3 feet 5 inches, minus the head of the bone, which is gone.

The late Rev. Mr. Layton possessed the finest collection of mammalian remains from the Norfolk coast. At his death it was purchased for the British Museum.

\section{NOTES ON DEEP OR ARTESIAN WELLS AT NORWICH.}

BY the Rev. J. Crompton.

The object of this paper is to put on record the facts connected with the attempt now being made by Messrs. J. and J. Colman, of London and Norwich, to bore a deep well through the chalk to the Lower Greensand. Mr. Rose, of Yarmouth, in the 'Proceedings of the Geologists' Associa-

* The atles of the Megaceros has a Turritella incrassata (Crag fossil) sticking in the canal for the vertebral artery. 